\title{
人工智能对设计的影响 \\ THE IMPACTS OF ARTIFICIAL INTELLIGENCE ON DESIGN
}

刘瑜
北京大学地球与空间科学学院遥感与地理信息系统研究所教授
北京市海淀区北京大学遥感楼1 11 室, 畉编: 100871

数据在人工智能领域的作用是什么? 如 果在城市尺度上运用人工智能技术, 是否会 有超出预期的发现?

刘瑜（以下简称刘）：从早期的初代人 工智能到机器学习, 再到深度学习, 虽然计 算机表现出的学习能力越来越强, 但其本质 上都需要进行数据的采集和分析、模式的寻 找和量化, 从而将这些数据和模式作为人工 智能的 “输人”。如果没有 “输人” 及针对 “输人” 进行的训练，任务就无法达成。所 以，数据的收集和模式的发现是人工智能进 行学习的基础

数据是否有价值取决于其本身是否蕴含 新的信息, 以及我们如何看待这些数据。借 助大数据获得的结论通常与人的常识认知基 本相符, 可能只在个别方面存在差异，而这 些差异正是大数据的价值所在。面对现实世 界，人类有其基本的价值判断，并且更倾向 于相信自己的判断。如果数据结果完全偏离常 识认知，我们通常会质疑数据的质量。更多时 候, 大数据的作用是对常识认知进行量化或补 充。所以，基于数据输人的人工智能在城市 尺度上不太可能有颠覆性的发现，但它会填 补我们的知识盲点, 并量化已有知识, 从而 帮助我们进行决策。
您认为目前深度学习的边界在哪里?

刘：作为当前人工智能的核心驱动技 术, 深度学习是基于多个层次的神经网络学 习, 它擅长提取深度特征。目前, 我们对人 工智能的训练都是在一个相对封闭的领域内 进行的。例如, 战胜世界顶级围棋高手李世 石的“阿尔法狗” (AlphaGo) 即便有超越 人类棋手的表现，它的智能性也只体现在围 棋这一特定领域，因为数据的输人和算法的 训练都是针对围棋规则进行的。目前能够实 现的人工智能一般被称为 “弱人工智能” , 它能够解决特定问题，且执行特定任务的能 力往往优于人类，但它没有自主意识。深度 学习使得机器能够被应用于众多领域, 但它 存在边界, 即便偶有跳脱出人类常识认知的

“创新” ，它的智能范围仍仅限于由人类划 分的特定领域或知识体系内。

\section{人工智能在现阶段具有哪些辅助设计} 功能?

刘：设计常介于科学与艺术之间, 这 意味着它在一定程度上是有规律可循的。例 如, 景观设计或城市规划都需要布局各个地 理要素 (如地质、地貌、水文等) 之间的关
摘要

本次访谈围绕人工智能及其可能的设计应用展开。受访人刘瑜深入浅 出地阐述了数据在人工智能领域的作用以及深度学习的边界问题, 并就人 工智能在现阶段能够发挥的辅助设计功能及其未来发展趋势进行了探讨。 刘瑜认为, 通过深度学习, 人工智能在相对封闭的领域内表现出色, 但相 比人类充满创造力和伦理性的开放式思维, 它仍存在局限, 特别是在介于 感性和理性之间的设计领域, 它无法取代人类设计师进行设计。尽管如 此, 设计师可以把一些常规的基础性工作交由人工智能去完成, 从而在设 计创新和用户沟通上投入更多精力。

关键词

人工智能; 数据; 深度学习; 设计; 黑箱; 白箱

\section{ABSTRACT}

This interview centers on Artificial Intelligence and its possible applications in design fields. Yu Liu, the interviewee, explains the role of data in Artificial Intelligence, the boundary for Deep Learning, Artificial Intelligence's function to aid design, and its future development. Liu also discusses how Artificial Intelligence can work within some particular fields, and the creative and ethical limits of Artificial Intelligence, especially in the design fields, which are between sensibility and rationality. Besides, he explains why Artificial Intelligence cannot take the place of human designers. In spite of this, Artificial Intelligence can be used to do repetitive or routine tasks so that designers can put more focus on design innovation and user experience optimization.

\section{KEY WORDS}

Artificial Intelligence; Data; Deep Learning; Design; Black Box; White Box

采访 余依爽 田晓款 王楠

整理 田晓劼 余依爽

译 萨拉・雅各布斯 黄延峰

INTERVIEWED BY Yishuang SHE Xiaojie TIAN Nancy WANG

EDITED BY Xiaojie TIAN Yishuang SHE

TRANSLATED BY Sara JACOBS Yanfeng HUANG 
系。所以, 对布局进行抽象并将其形式化, 可能是人工智能辅助设计的一个方向。同 时, 通过对足够多的设计原则和优秀设计案 例进行学习, 人工智能也可以在很大程度上 助力场地分析, 甚至生成一些可供遴选的初 步方案。此外, 设计师完全可以把一些基础 性常规工作交由人工智能去完成, 从而在设 计创新和用户沟通上投人更多精力。

除了辅助设计, 人工智能技术还能够 处理数量庞大的社会数据。随着未来科技的 发展, 人类的生产和生活方式可能会发生巨 大改变。如何利用人工智能技术进行科学的 设计决策, 以使公众更好地适应新的环境空 间, 是设计师应当关注的方向之一。

\section{您认为我们是否有必要为人工智能可能 取代人类设计师而担忧?}

刘：在历史上, 人类被机器超越是常 有之事。例如，随着机械时代的到来，人们 发现机器的体力和效率远高于人类; 在计算 机时代, 机器的运算速度和准确率超越了人 类; 经过当代的进一步发展, 以“阿尔法 狗” 为代表的机器人在围棋领域战胜了人 类。人们之所以对最后一种超越反应强烈, 或许是因为我们视围棋领域为人类智慧的专 属。事实上, “阿尔法狗” 只是将围棋简化 为算法, 通过深度学习掌握了更为抽象的概 念, 但它并没有自我意识与独立思考能力。

相较而言, 人类的思维是开放的、无穷 尽的, 且充满了灵感与创造力。我认为能够 被学习或被复制的模式是不具备创造力的。 比如人工智能在学习了毕加索的画风之后, 可以 “画” 得很像毕加索, 但它永远无法超 越毕加索, 更不能被称作伟大的艺术家。此 外, 人不仅能够运算和判断, 而且还具有情 感和伦理道德观念。在可见的未来, 人工智 能不可能具备人类的这些特质。设计通常兼 具感性和理性, 虽然设计本身难以被取代, 但其中那些可以根据内在逻辑和规则形成封闭 空间的部分, 则可以交由人工智能去完成。有 了这个帮手, 设计师可以有时间和精力去做更 多有意义的事，从而发挥更大的创造力。

\section{您认为人工智能未来将朝着怎样的方向} 发展?

刘: 人工智能的发展其实是黑箱和白箱 ${ }^{(}$ 交替发展的过程。以战胜国际象棋世界冠军 加里 - 卡斯帕罗夫的超级计算机 “深蓝” 为 例, 我们可以明确其算法是基于穷举搜索, 也可以理解其每一步的决策机制, 所以当时 的人工智能尚处于白箱阶段。而最新发展的 以深度学习为基础的人工智能, 其运作过程 犹如黑箱作业, 人们往往无法理解其算法的 决策依据, 甚至连开发者也难以具体说明其 决策机制。未来要想更好地利用人工智能, 就必须使黑箱变为白箱, 了解其算法和决策 依据, 只有这样, 我们才能更合理地判断是 否采纳其所提供的决策建议。

此外, 由于深度学习是基于人工神经网 络的学习, 所以涉及到人工智能和神经生物 学的交叉合作和相互促进。也就是说, 人类 对自身的认识越清晰, 越有利于人工智能的 发展。所以, 我认为今后对人工智能的研究 不仅会更加侧重于白箱, 而且会更加关注对 人类自身的研究, 例如探讨人如何思考、人 的记忆如何产生等。

\section{人工智能将如何影响我们的未来生活?}

刘: 人工智能连同其他计算机信息技术 将在很大程度上改变我们未来的生活方式, 以及人与人之间的沟通模式。技术正以非线 性的加速度飞速发展着。30年前的1988年, 互联网仍未普及, 当时的人们完全无法想象 今天的信息技术会有如此惊人的突破, 移动 互联网、共享单车、电子支付等技术及应用 层出不穷。展望30年后的2048年, 信息技术 发展的量级会更加巨大, 人工智能对我们未 来生活的影响也难以预测, 而增强现实和虚 拟现实技术的发展可能会给城市生活带来更 多崭新的图景。LAF 
What is the role of data in the field of Artificial Intelligence (AI)? Will AI discover anything that goes beyond human's expectations at the city scale?

Yu LIU (LIU hereafter): From the early generation of AI to Machine Learning and to Deep Learning of today, the essence of AI has remained the same. AI needs to collect and analyze data, and search for and quantify patterns which then can be used as an input. Tasks cannot be achieved without inputs or training for inputs. Therefore, the collection of data and the induction of patterns are the basis of AI.

The value of data depends on whether the data itself contains new information and how we then use that data. The conclusions reached from big data are consistent with human cognition, except for the slight differences that reveal the value of big data. As humans are more inclined to believe in their own judgments, if the data results seem unrealistic, we tend to think there is a problem with data quality. More often, big data helps quantify our cognition and supplement our knowledge. Therefore, AI based on data input is not likely to lead to surprising discoveries, but rather it supplements our knowledge of blind spots and quantifies existing knowledge to aid in decision-making.

Where do you think the boundary for Deep Learning is currently?

LIU: As the key driver of AI, Deep Learning is based on multiple levels of neural networks that can extract indepth features. Currently, AI training is relatively delimited. For example, even if the AI program AlphaGo defeated the world's top professional Go player, Lee Sedol, its intelligence is only in the specific field of Go Game, since its data input and training is only for the game rules. What we can achieve now is called "Narrow AI," which can be used to solve given problems and tasks without selfawareness of problem-finding or learning. Although with Deep Learning machines can perform excellently in many fields, and even go far beyond our expectations sometimes, the good use of AI is limited within a few particular domains or knowledge systems, due to the boundaries of the related input and training.

\section{In which ways can the current AI} technology aid design?

LIU: Design is always between science and art and it follows rules. For example, in the fields of landscape design and urban planning, we need to clarify the relationships between various geographical elements such as geology, landform, and hydrology. Abstracting the layout of these elements and then formalizing it may be a direction of AIaided design. In the future, AI may help designers do site analysis, or even develop preliminary plans through the input of relevant design principles and sufficient design cases. In addition, designers could hand over repetitive or routine tasks to AI, which allows human designers to pay more attention to design innovation and user experience optimization.

$\mathrm{AI}$ is also able to process a large amount of social data. With the development of science and technology, human life will change dramatically. One of the research directions that designers should be concerned with is how to use AI technologies to help designers work more scientifically to better adapt design plans to contemporary changes in urban life.

How do you look at the anxiety about AI as a substitute for human designers? 
LIU: Historically, human beings have long been outdone by machines. Since the machine age, they have been used to perform human functions at higher rates of strength and efficiency. Today, computers can do better jobs than humans in many fields, even at playing Go! We over react to this type of information because we believe that activities like playing Go are a privilege of human intelligence. But, in fact, AlphaGo just simplifies the Go Game to an algorithm, and it still has no self-awareness or capacity of thinking.

In contrast, human thinking is open, endless, and full of inspiration and creativity. AI could learn to paint like Picasso, but it will never surpass Picasso or be a great artist. Humans are rich with emotion and ethic, while AI does not and would not have these characteristics in the foreseeable future. Design is difficult to be replaced since it works between sensibility and rationality. However, AI can do basic work. With AI's help, human designers could save time and energy to do more meaningful things and develop their creativity.

\section{What do you think is the future of AI?}

LIU: The development of AI is actually an alternate development process of black box and white box ${ }^{(1)}$. To take supercomputer "Deep Blue" which defeated world chess champion Garry Kasparov as an example, we know its algorithm is based on exhaustive search, and its decision-making mechanism is understandable. Therefore, AI was in the stage of white box at that time. Today, the latest development of $\mathrm{AI}$ is based on Deep Learning and its operation process is like a black box operation as people often cannot understand the decision-making basis of the algorithm or even developers have a hard time understanding specific decisionmaking mechanisms. To make better use of $\mathrm{AI}$ in the future, we must understand AI algorithms - turning it from the black box to a white box - as the basis for decision-making. Only in this way can we decide more rationally whether to accept the results of AI algorithms or not.

Deep Learning is based on the study of artificial neural networks, and there has been a lot of collaborations and mutual promotion between AI and neurobiology. The more humans know about themselves, the more conducive to the development of AI. In the next few years, the study of AI will pay more attention to the research of human cognition to explore how we think and how memory is generated.

\section{How will AI affect our lives in the future?}

LIU: AI, along with other computer information technologies, will greatly change our lifestyle and communication patterns in the future. The development of technology is accelerating nonlinearly. Thirty years ago, it would have been impossible to imagine that information technology would make such amazing break throughs like nowadays. At that time, the Internet was not yet popular, certainly no mobile internet, shared bicycles, or electronic payments. Looking forward 30 years later, the magnitude of information technology development will be even greater, the impact of $\mathrm{AI}$ on our future is unpredictable, and the development of augmented reality and virtual reality may bring a new picture to our city life. LAF 